\title{
Time Management and its Impact among Medical Laboratory Science Students' Academic Performance and Engagement
}

\author{
MICHELLE T. MABASA \\ ORCID No. 0000-0001-8502-9803 \\ emimabz@yahoo.com \\ Liceo de Cagayan University \\ Cagayan de Oro City, Philippines
}

\begin{abstract}
Various researches have shown student engagement and academic performance as important predictors to educational success. This paper focused on determining the impact of time management factor on academic performance and engagement. Using frequency, chi-square, correlation and regression analysis, the relationship and effect of time management to student engagement and academic performance were examined among 102 regular junior Medical Laboratory Science students of Liceo de Cagayan University for the first semester of school year 2014-2015. The results revealed that in terms of time management, only a little more than half of the student-respondents feel they are in-charge of their time and sixty percent have good planning skills whether short-range or long-range planning. The results further revealed that student engagement, not academic performance, figured out prominently as the variable that bear on time management of the students. These findings support the need for review of procedures and structures of the College or the University in motivating students towards behavioral, cognitive and social engagement.
\end{abstract}

Keywords: Time management, student engagement, academic performance, medical laboratory science

\section{INTRODUCTION}

Students are potential nation builders and their ability to successfully attain a college degree is of interest to the school, their families, and the students themselves. 
There are, however, many obstacles that a student must overcome to achieve their desired college degree. The extent to which a student has achieved learning is measured by their academic performance. A good performance is evidenced by good or high grades while a poor performance is marked by a low or failing grade. It makes no sense to have goals in place without being able to measure to what extent they have been achieved (Danielson, 2002).

Schools are likewise focused not only on making education accessible to students but also in retaining them until they finish. In today's highly competitive education market, the concern is not only ensuring that students stay and graduate but also to increase student retention rate (Cinches, 2015). This becomes one of the most crucial issues for higher educational institutions to be successful according to Leone and Tian (2009).

Time management is invaluable for academic success. Ferrett (2010) asserts that being efficient is about doing things faster while being effective is about doing the right things in the right way. It is reasonable to deduce that success in the academe requires efficient time management to be developed and nurtured.

Medical Laboratory Science is one of the hardest and most demanding courses at Liceo de Cagayan University. Being the only school in Misamis Oriental to offer Bachelor in Medical Laboratory Science or Bachelor of Science in Medical Technology, the college aims to uphold quality and good performance of faculty, staff and most especially its students. Though students passed the entrance exam and requirements to enrol in Medical Laboratory Science, the declining number of students passing their subjects each semester as they move to their higher years is quite alarming. Some of them even gets debarred and shift to other courses or transfer to another school. This study looked closely on how the time management factor explains academic performance as well as their engagement in school.

\section{OBJECTIVES OF THE STUDY}

This study specifically pursued the following objectives: 1) to describe the time management amonth Medical Laboratory Science students in terms of short range planning, time attitude, and long-range planning; 2) to describe the students' behavioral, intellectual, and emotional engagement; 3) to find out the students' academic performance; and 4) to relate time management to student engagement and academic performance. 


\section{CONCEPTUAL FRAMEWORK}

Student engagement is a major focus in this study because numerous investigations have revealed that this is a strong component for retaining students. The term student engagement has developed over time through the efforts of several theorists and educational researches. Astin $(1984,1999)$, in his Developmental Theory on Student Involvement defines student involvement as the amount of physical and psychological energy that the student devotes to the academic experience. He goes on to define a highly involved student as one who devotes considerable amount of time and energy to studying, spending much time on campus, participates actively in student organizations and interacts frequently with faculty members or other students. An uninvolved student meanwhile is described as the opposite. He further enumerates five postulates to his theory. First is that involvement refers to the investment of physical and psychological energy in various objects. Second that regardless of object, involvement occurs along a continuum. Third, involvement has both quantitative and qualitative features. Fourth is the amount of student learning and personal development associated with any educational program is directly proportional to the quality and quantity of student involvement in that program. Lastly, the effectiveness of any educational policy or practice is directly related to the capacity of that policy or practice to increase student involvement. The last two postulates however are subject to empirical proof. Kuh (2003), on the other hand, describes student engagement as the time and energy that students devote to educationally sound activities inside and outside of the classroom, and the policies and practices that institutions use to induce students to take part in these activities. Kuh (2003) asserts that student engagement is the key to academic success.

One theory relating to academic performance is the system's theory of inputoutput model developed by Ludwig Von Bertalanffy in 1956. As cited by Kyoshaba (2009), the theory postulates that an organized enterprise does not exist in a vacuum; it is dependent on its environment in which it is established. Inputs from the environment are then transformed into outputs. Another theory on academic performance is the theory of performance by Elger (2007). He defined performance as to taking a complex series of actions that integrate skills and knowledge to produce a valuable result. These results however are affected by context, personal factors, level of knowledge and level of skills to name some. Several factors have been initially identified earlier to have bearings on academic performance and student engagement. Among these is time management.

Time management is central to this study because it points to the students' ability to maximize the whole course experience especially in studying considering the limited 
time of stay in the college.

Time management is defined as the efficient use of all resources to achieve a purpose, perform work, or conduct activities in a time period for which the beginning and end are determined (Akatay, 2003). The purpose of time management is not to increase a limited time but to increase the quality of the activities carried out in the limited time (Erdem, Pirinçci and Dikmetas, 2005). Running out of time is a serious obstacle for students who cannot use the resource of time efficiently.

The Britton and Tesser (1991) model on time management conceptualizes that good or effective time management can contribute to higher levels of college achievement. They found out that self-reported time management predicted academic achievement and, in particular, it was short-term planning that predicted grade point average.

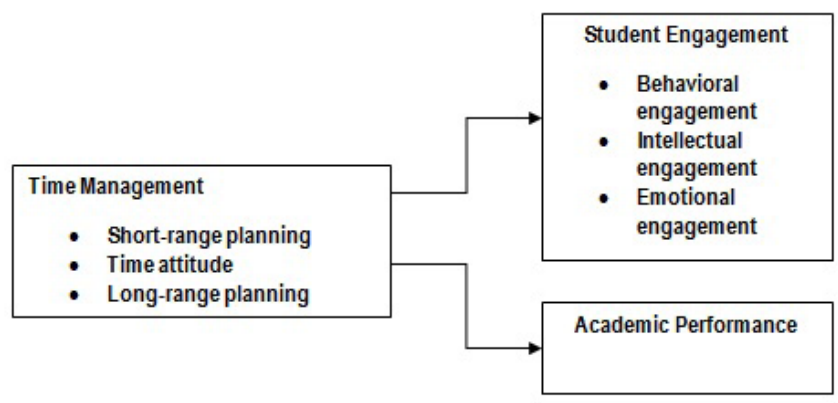

Figure 1. Schematic Diagram

Given the conceptions of different scholars, experts and practitioners in the field of education regarding the dynamics of what make students perform academically and what make them stay and finish, Figure 1, summarily explains the intent of this current study. Figure 1 shows the conceptual framework of the study. It is assumed that the students' time management skills influence the student's level of engagement and academic performance.

\section{METHODOLOGY}

Students of Liceo de Cagayan University are coming from different places in Mindanao. Since the institution is practicing open admission policy, students are accepted regardless of their performance in the entrance exam and their high school grades making the group heterogeneous. 
Majority of the course subjects offered in the third-year level are major subjects or professional subjects because these are the subjects covered in the MEDTECH Licensure Examination conducted by the Professional Regulation Commission (PRC). Furthermore, these subjects are divided into lecture and laboratory, the lecture portion are being handled mostly by doctors or pathologists while the laboratory part is handled by registered medical technologists.

There were 138 junior students in the College of Medical Laboratory Science enrolled in the first semester of SY 2014-2015. Only regular students, those carrying the full load for the given semester, and still enrolled in the college during the second semester were utilized in the study totalling to a sample size of 102 . The junior students were specifically selected as respondents in this study because these students were the ones subjected to the debarment policy. Debarment policy of the college states that those students who acquire three (3) failures in any of the major subjects in a semester will be disqualified from re-admission to the program, as stated in the Liceo de Cagayan University College Student Handbook, Revised Edition 2012, page 25. The Time Management Questionnaire developed by Britton and Tesser (1991) was used to determine the level of time management of the student-respondents as to: short-range planning; time attitude; and long-range planning.

The National Survey of Student Engagement (NSSE) of 2006 was utilized to determine level of student engagement. According to Kerby (2007), the instrument was divided into three sections that consisted of items designed to measure student engagement. This includes behavioral engagement or the activities in which students participated outside of the classroom. Participants were asked to report how often (e.g. very often; often; sometimes; never) they engage in activities ranging from working with faculty members outside of class to membership in student organizations. The second set of items measures the intellectual or cognitive engagement of the student. The participants were asked to report to what extent (e.g., very much; quite a bit; some; very little) their experiences at their institution contributed to their knowledge, skills, personal development in class and contribution to the general welfare of the community. The final set, emotional engagement, explores the views of the students on important aspects of their college environment.

To determine the academic performance of the student, the quality point index or QPI was computed from grades acquired by the student for the first semester of the school year 2014-2015. To interpret the level of academic performance, the following grade ranges for their QPI was utilized with its corresponding verbal descriptions:

Pearson product moment correlation coefficient $(r)$ was used to measure degree of relationship between the independent variable to student engagement and academic performance. 
Table 1. Verbal descriptions of QPI

\begin{tabular}{cc}
\hline GRADE & INTERPRETATION \\
\hline $1.5-1.0$ & Excellent \\
$(90-95)$ & Very Good \\
$2.0-1.6$ & \\
$(85-89)$ & Good \\
$2.5-2.1$ & \\
$(80-84)$ & Fair \\
$3.0-2.6$ & Poor Failed \\
$(75-79)$ & and below \\
\hline
\end{tabular}

Multiple Linear Regression (MLR) was used to determine extent of influence of time management on student engagement and academic performance in terms of QPI.

\section{RESULTS AND DISCUSSION}

The initial population chosen for this study was the entire junior medical laboratory science students of the first semester of the school year 2014-2015 $(\mathrm{N}=137)$. To establish homogeneity of sample, irregular students (students with less or more subject load) and those that were advised to shift after the first semester were excluded from the sampling procedure resulting to a final sample size of 102 .

Time management constitutes one of the most traditional topics in the field of learning. One of the most common complaints of the students is that they don't have enough time to carry out all tasks assigned to them both in high school as well as in college (Nadinloyi, Hajloo, Garamaleki and Sadeghi, 2013). Britton and Tesser (1991) proposed that differences among individuals in time management practices accounts for some of the differences in how much people achieve during their college years. By using the "Time Management Questionnaire" developed by the same authors, the student-respondents skill level in terms of short-range planning, time attitude and long-range planning are presented.

Short-range planning indicators encompass a variety of items that require planning in the short run, either within the day or within the week (Britton and Tesser, 1991). The study reveals in table 2 that in terms of short-range planning, almost (60\%) of the student-respondents possess good to excellent time management. Almost all of the indicators were rated as "Often (At least $75 \%$ of the time)" with only three indicators, numbers 31,34 and 36 which pertains to goal setting and daily planning, got a rating of "Sometimes (At least $50 \%$ of the time)". 
Table 2. Frequency and Percentage Distribution of Students' Responses for Short-Range Planning in Time Management $(n=102)$

\begin{tabular}{|c|c|c|c|c|}
\hline Range & $\begin{array}{l}\text { Point } \\
\text { Value }\end{array}$ & Description & Frequency & Percent \\
\hline $1.00-1.50$ & 1 & Rarely (Up to $25 \%$ of the time) & 1 & 1.0 \\
\hline $1.51-2.50$ & 2 & Sometimes (At least $50 \%$ of the time) & 40 & 39.2 \\
\hline $2.51-3.50$ & 3 & Often (At least $75 \%$ of the time) & 53 & 52.0 \\
\hline \multirow[t]{2}{*}{$3.51-4.00$} & 4 & Almost Always (At least $95 \%$ of the time) & 8 & 7.8 \\
\hline & & Total & 102 & 100.0 \\
\hline
\end{tabular}

Students who scored high on this dimension tend to organize their day. Since college life can easily get muddled with all the projects, assignments, almost daily quizzes, practical exams and of course the students' social life that they have to balance, having a clear idea in advance of what needs to be accomplished daily can be very beneficial to a medical laboratory science student. Unfortunately though, the remaining (40\%) of the student-respondents have poor to fair short-range planning skill. As an instructor, this researcher have observed this in several medical laboratory science students who tend to work on assignments or laboratory guide questions a few minutes before submission deadline.

Table 3. Frequency and Percentage Distribution of Students' Responses for Time Attitude in Time Management ( $\mathrm{n}=102)$

\begin{tabular}{|c|c|c|c|c|}
\hline Range & $\begin{array}{l}\text { Point } \\
\text { Value }\end{array}$ & Description & Frequency & Percent \\
\hline $1.00-1.50$ & 1 & Rarely (Up to $25 \%$ of the time) & 0 & 0 \\
\hline $1.51-2.50$ & 2 & Sometimes (At least $50 \%$ of the time) & 47 & 46.1 \\
\hline $2.51-3.50$ & 3 & Often (At least $75 \%$ of the time) & 55 & 53.9 \\
\hline \multirow[t]{2}{*}{$3.51-4.00$} & 4 & Almost Always (At least $95 \%$ of the time) & 0 & 0 \\
\hline & & Total & 102 & 100.0 \\
\hline
\end{tabular}

The second dimension in time management is time attitude. This scale is more attitudinal in nature (Britton and Tesser, 1991). Table 3 shows that most, almost (54\%), of the student-respondents often (at least $75 \%$ of the time) feel they are in charge of the way their time is spent. But many (46\%) feel that they are in charge sometimes (at least $50 \%$ of the time) only. This is evident in their response to indicator number 39, which establishes whether they believe that they can improve the way they manage their time, and majority of the response is "Rarely (Up to 25\% 
of the time)". This can also be seen in their response to indicator number 40 which determines their capability to say NO to other things that might interfere with their schoolwork. The average (2.41) of the student-respondents score on this indicator shows that they are only sometimes able to do so. The overall mean is 2.54 where 4 is the highest in the scale. This is inferred as "Often (At least $75 \%$ of the time)." Medical laboratory science students need to have a strong sense of control over their time. This is imperative so as not to get overwhelmed by the bulk of academic requirements or side-tracked by unprofitable activities.

Table 4. Frequency and Percentage Distribution of Students' Responses for Long-Range Planning in Time Management $(n=102)$

\begin{tabular}{|c|c|c|c|c|}
\hline Range & $\begin{array}{l}\text { Point } \\
\text { Value }\end{array}$ & Description & Frequency & Percent \\
\hline $1.00-1.50$ & 1 & Rarely (Up to $25 \%$ of the time) & 1 & 1.0 \\
\hline $1.51-2.50$ & 2 & Sometimes (At least $50 \%$ of the time) & 39 & 38.2 \\
\hline $2.51-3.50$ & 3 & Often (At least $75 \%$ of the time) & 59 & 57.8 \\
\hline \multirow[t]{2}{*}{$3.51-4.00$} & 4 & Almost Always (At least $95 \%$ of the time) & 3 & 2.9 \\
\hline & & Total & 102 & 100.0 \\
\hline
\end{tabular}

Table 4 presents another aspect of time management which is long range planning. The general average of the scores is 2.63 which mean "Often (At least $75 \%$ of the time)". Only indicators number 44 and 48, determining the planning skill of the student-respondents in terms of making assignments and reviewing class notes were rated as "Sometimes (At least $50 \%$ of the time)". Slightly more than half of the student-respondents (58\%) often (At least $75 \%$ of the time) plan for their future but the remaining (40\%) student-respondents score poor to fair in their longrange planning skills. Students who score high on this dimension seem to think of things in terms of a relatively wide window. They review materials even when tests are not imminent and do not wait until the last minute to finish working on major assignments (Britton and Tesser, 1991). This signifies that some medical laboratory science students have not developed the habit of reviewing notes even though there are no tests. Some tend to concentrate only on current subject topics just to get-by the semester.

Another defining variable looked into this study is the level of student engagement. This refers to the students' level of involvement in college at the behavioral, intellectual/cognitive and emotional level both inside and outside the classroom (Fredricks, Blumenfield, \& Paris, 2004). It is believed that the more 
engaged the student, the better he is in terms of his academics. The National Survey of Student Engagement (NSSE) solicits information detailing the frequency in which students engage in activities within the confines of the four corners of the classroom or beyond. The instrument was divided into three sections that were designed to measure student engagement which include the following: College activities or behavioral engagement, Educational and personal growth or intellectual/cognitive engagement and Opinion about your school or emotional engagement.

Table 5. Frequency and Percentage Distribution of Students' Responses for Behavioral Student Engagement $(\mathrm{n}=102)$

\begin{tabular}{|c|c|c|c|c|c|}
\hline Range & $\begin{array}{l}\text { Point } \\
\text { Value }\end{array}$ & Description & & Frequency & Percent \\
\hline $1.00-1.50$ & 1 & Never & & 0 & 0 \\
\hline $1.51-2.50$ & 2 & Sometimes & & 60 & 58.8 \\
\hline $2.51-3.50$ & 3 & Often & & 42 & 41.2 \\
\hline \multirow[t]{2}{*}{$3.51-4.00$} & 4 & Very often & & 0 & 0 \\
\hline & & & Total & 102 & 100.0 \\
\hline
\end{tabular}

The level of behavioral engagement points up to the student's involvement in campus activities or college activities as well as the time spent on campus. Moreover, the indicators in this scale evaluate student-to-student interaction, such as membership in student organizations, and also faculty-to-student interaction. As can be seen in table 5, most of the student-respondents, almost (59\%), are only sometimes engaged behaviorally while the remaining (41\%) is oftentimes behaviorally engaged.

As mentioned previously, the bulk of the course load in third-year level are board or professional subjects. Junior medical laboratory science students, who are the respondents of this study, are more inclined to focus on their academic tasks than to get involved with extracurricular activities.

Table 6. Frequency and Percentage Distribution of Students' Responses for Intellectual/Cognitive Student Engagement ( $\mathrm{n}=102)$

\begin{tabular}{|c|c|c|c|c|c|}
\hline Range & $\begin{array}{l}\text { Point } \\
\text { Value }\end{array}$ & Description & & Frequency & Percent \\
\hline $1.00-1.50$ & 1 & Very little & & 0 & 0 \\
\hline $1.51-2.50$ & 2 & Some & & 9 & 8.8 \\
\hline $2.51-3.50$ & 3 & Quite a bit & & 76 & 74.5 \\
\hline \multirow[t]{2}{*}{$3.51-4.00$} & 4 & Very much & & 17 & 16.7 \\
\hline & & & Total & 102 & 100.0 \\
\hline
\end{tabular}


Table 6 shows that majority or (75\%) of the student-respondents are to a degree intellectually engaged. In fact almost all of the indicators were rated as "Quite a bit" with only indicator letter " $i$ ", on practicing their right to vote, was rated as "Some". Intellectual or cognitive engagement scale created questions to measure the extent of the contribution of the school or institution to the students' educational and personal growth. True to its mission in delivering quality education, Liceo de Cagayan University has provided the college of medical laboratory science ample aid to assure superior teaching-learning experience. This aid comes in the form of different machines and equipments such as: blood chemistry analyzer, microscopes, microtome, venipuncture arm, even LCD projectors, etc., that are made readily available to the students to facilitate their learning experience. Aside from that, community service or community involvement is cultivated in the students to assist in their personal growth as potential future nation builders.

Table 7. Frequency and Percentage Distribution of Students' Responses for Emotional Student Engagement $(\mathrm{n}=102)$

\begin{tabular}{|c|c|c|c|c|}
\hline Range & $\begin{array}{l}\text { Point } \\
\text { Value }\end{array}$ & Description & Frequency & Percent \\
\hline $1.00-1.50$ & 1 & Very little/Poor/Definitely No & 1 & 1.0 \\
\hline $1.51-2.50$ & 2 & Some/Fair/Probably No & 20 & 19.6 \\
\hline $2.51-3.50$ & 3 & Quite a Bit GoodProbably Yes & 73 & 71.6 \\
\hline \multirow[t]{2}{*}{$3.51-4.00$} & 4 & Very Much/ExcellentDefinitely Yes & 8 & 7.8 \\
\hline & & Total & 102 & 100.0 \\
\hline
\end{tabular}

The final set of scaled items for student engagement is the emotional engagement. Indicators for this sub dimension demonstrate the student's opinion about the school. It explores the student's views of important aspects of their college environment (Kerby, 2007). Kuh (2001) viewed it as the emotional tie of the students to the institution. The more committed the institution, the more likelihood that students will persist. It was Tinto (1975) who initially conceptualized the idea of goal and institutional commitment as a predictor of persistence in higher education.

Results in table 7 revealed that almost (72\%) of the student-respondents agree to some extent on the emotional engagement indicators particularly since only indicator letter "d", about helping students cope with non-academic responsibilities, was rated as "Some". All the other indicators were rated as "Quite a bit". An average of (3.15), "Good", were garnered on the indicators regarding the quality of education received 
and how they rate their entire educational experience. As to the question of whether they would re-enrol to the same institution (indicator number 6), the mean score was 3.14 meaning "Probably Yes".

Table 8. Frequency and Percentage Distribution of Students' Academic Performance for the 1st Semester of SY 2014-2015 ( $\mathrm{n}=102)$

\begin{tabular}{|c|c|c|c|c|}
\hline Range & Description & & Frequency & Percent \\
\hline 3.1 and below & Poor/Failed & & 32 & 31.4 \\
\hline $3.0-2.6$ & Fair & & 36 & 35.3 \\
\hline $2.5-2.1$ & Good & & 21 & 20.6 \\
\hline $2.0-1.6$ & Very Good & & 11 & 10.8 \\
\hline \multirow[t]{2}{*}{$1.5-1.0$} & Excellent & & 2 & 2.0 \\
\hline & & Total & 102 & 100.0 \\
\hline
\end{tabular}

In this study, academic performance was conceptualized as the quality point index (QPI) of the student-respondents. QPI which was calculated from the major or board subjects of the first semester of the school year 2014-2015.

Table 8 shows that thirty-six (36) or 35\% of the student-respondents have fair grades. Twenty-one (21) or almost $21 \%$ have good grades. Eleven (11) or almost $12 \%$ attained very good grades and only two (2) or $2 \%$ garnered an excellent mark. This implies that majority, almost (69\%) of the student-respondents passed their major subjects and that most of them earned fair grades which is anywhere from 2.6 to 3.0. The passing mark for the medical laboratory science department is set at 3.0 or $75 \%$.

Another purpose of this study was to examine the levels of relationship between the independent variable to the student-respondents level of engagement and academic performance. The Pearson product-moment correlation coefficient ( $\mathrm{r}$ ) was used to compute the relationship between time management skills on student engagement and academic performance.

Using the Pearson product-moment correlation coefficient (r), the outcome is presented in Table 9. The results suggest that 4 correlations were statistically significant. These are the correlations between the short-range planning variable in time management skills and the level of student engagement in terms of behavioral engagement, $r(101)=.315, \mathrm{p}<.01$, two-tailed; intellectual engagement, $r(101)$ $=.270, \mathrm{p}<.01$, two-tailed; and emotional engagement, $\mathrm{r}(101)=.267, \mathrm{p}<.01$, two-tailed. Correlation between time attitude variable and intellectual student engagement, $\mathrm{r}(101)=.303, \mathrm{p}<.01$, two-tailed, also yielded a statistically significant outcome. 
Table 9. Relationship between Time Management Skills on Student Engagement and Academic Performance $(n=102)$

\begin{tabular}{rcccccc}
\hline $\begin{array}{c}\text { Student } \\
\text { Engagement }\end{array}$ & $\begin{array}{c}\text { Short-range Planning } \\
\text { Pearson r }\end{array}$ & \multicolumn{2}{c}{$\begin{array}{c}\text { Time Management } \\
\text { Time Attitude } \\
\text { p-values }\end{array}$} & $\begin{array}{c}\text { Learson r } \\
\text { p-values }\end{array}$ & $\begin{array}{c}\text { Long-range Planning } \\
\text { Pearson r }\end{array}$ & p-values \\
\hline Behavioral & $.315^{* 8}$ & $.001 \mathrm{~S}$ & .014 & $.888 \mathrm{NS}$ & .130 & $.193 \mathrm{NS}$ \\
Intellectual & $.270^{* *}$ & $.006 \mathrm{~S}$ & $.303^{* *}$ & $.002 \mathrm{~S}$ & .175 & $.078 \mathrm{NS}$ \\
$\begin{array}{c}\text { Emotional } \\
\text { Academic }\end{array}$ & $.267^{* *}$ & $.007 \mathrm{~S}$ & .092 & $.356 \mathrm{NS}$ & .122 & $.221 \mathrm{NS}$ \\
$\begin{array}{c}\text { Performance } \\
\text { ** Correlation is significant at the 0.01 level (2-tailed) }\end{array}$ & -.005 & $.961 \mathrm{NS}$ & .091 & $.365 \mathrm{NS}$ & .022 & $.824 \mathrm{NS}$ \\
\hline
\end{tabular}

The correlations of academic performance with all the time management skills sub-dimensions were all not statistically significant. This is unlike the study of Pehlivan (2013) wherein there exist a positive significant relationship $(\mathrm{r}=0.052$, $\mathrm{p}$ $<0.01$ ) only between time attitudes and grade point average of financial accounting students. The researcher is taking into consideration that the p-value of the above mentioned study is marginal. Another study on the effect of time management skills on academic performance was done by Sansgiry et al. (2006). The factors that affect the academic performance among pharmacy students in the University of Houston were looked into but data reveals no significant correlation between time management and academic performance.

Table 10. Multiple Linear Regression Analysis between Time Management Skills and Students Engagement (SEAV)

\begin{tabular}{|c|c|c|c|c|}
\hline \multicolumn{2}{|c|}{ Independent Variables } & $\begin{array}{l}\text { Regression } \\
\text { Coefficients }\end{array}$ & $\mathbf{t}$ & P-Value \\
\hline \multicolumn{2}{|c|}{ Short-Range Planning (TMSAV) } & .330 & 2.949 & $.004 \mathrm{~S}$ \\
\hline \multicolumn{2}{|c|}{ Time Attitude (TMTAV) } & -.019 & -.187 & $.852 \mathrm{NS}$ \\
\hline \multicolumn{2}{|c|}{ Long-Range Planning (TMLAV) } & .005 & .046 & $.963 \mathrm{NS}$ \\
\hline $\begin{array}{l}\text { Constant } \\
\text { Adjusted } R^{2} \\
\text { F-value } \\
\text { Sig. Level }\end{array}$ & $\begin{array}{l}: 1.579 \\
: 0.079 \\
: 3.894 \\
: 0.011\end{array}$ & & & \\
\hline
\end{tabular}

Table 10 shows the influence of the sub-dimensions of time management on student engagement. The value of adjusted R2 indicates that $7.9 \%$ of the variation of the student engagement can be predicted from their time management skills. With an f-value of 3.894 , the model is significant at 0.011 . The table further reveals that only short-range planning has a significant relationship on the student engagement. The results obtained from regression analysis indicate the 0.5 significance level coefficient of answers provided to the questions on "Short-Range Planning" (TMSAV) is (0.330). 
Moreover, the figures in the table disclose that for every unit change in the shortrange planning skills of the students, there is a corresponding increase of 0.330 in the level of student engagement. This further means that the higher their skills in terms of short-range planning, the more engaged the students will be behaviorally, intellectually and emotionally. In the study of Duplito (2013) entitled "The Dynamics of Dispositional Traits and Student Engagement: The Case of The Commission On Higher Education Region 10 Scholars" she stated that students are engaged when they "devote substantial time and effort to a task, when they care about the quality of their work, and when they commit themselves because the work seems to have significance beyond its personal instrumental value" (Newmann, 1989, p. 242 as cited by Duplito, 2013). Drawing connections between information taught and real life is highly effective in engaging students in the lesson (Heller et al., 2003 as cited by Duplito, 2013). To a certain extent, the result of this study supports Duplito's findings in that the whole set of time management variables taken as one explains almost $8 \%$ of the variation in student engagement.

\section{CONCLUSIONS}

The study aimed to investigate the impact of time management skills on level of student engagement and academic performance of the junior students based on conceptual and research literature discussed. It is in this premise that the conclusions were drawn:

Student engagement figured out prominently as the variable that bear on the time management skills of the students. Tinto (2006) said that student engagement impact on the decision of students to stay in the institution. Student retention is one of the most crucial issues for higher educational institutions (Leone and Tian, 2009) to include Liceo de Cagayan University, that is, to successfully transition students to graduate. This can be highly affected by enhancing student interaction and engagement in the institution (Tinto, 2006). This finding finds its significance on the need for review of procedures and structures of the College or the University in motivating them towards behavioral, cognitive and social engagement.

\section{LITERATURE CITED}

Akatay, A.

2003 The time management in organizations. Selçuk Üniversitesi Sosyal Bilimler Enstitütü Dergisi, No.10, pp:282-300. 
Astin, A. W.

1984 Student Involvement: A developmental theory for higher education. Journal of College Student Development, 25(4): 297-308.

Astin, A. W., Sax, L. J. \& Avalos, J.

1999 Long-term effects of volunteerism during the undergraduate years. The Review of Higher Education, 22(2): 187-202.

Britton, B.K. \& Tesser, A.

1991 Effects of time-management practices on college grades, Journal of Educational Psychology, Vol. 83, pp. 405-10.

Cinches, M.F.

2015 A survey of opinions among students on reasons for choosing and staying with the university: An institutional study. University Planning Office, Liceo de Cagayan University

Danielson, C.

2002 Enhancing student engagement: A framework for school improvement. Association for Supervision and Curriculum Development, USA.

Duplito, J.

2013 The dynamics of dispositional traits and student engagement: The case of the Commission on Higher Education Region 10 scholars. Unpublished Master's Thesis, Lourdes College, Cagayan de Oro City, Philippines

Elger, D.

2007 Theory of performance. In S.W. Beyerlein, C. Holmes, \& D. K. Apple (Eds.), Faculty guidebook: A comprehensive tool for improving faculty performance (4th ed.) (19-22). Lisle, IL: Pacific Crest. Retrieved from http://www.webpages.uidaho.edu/ele/ Scholars/Results/Workshops/Facilitators_Institute/Theory \%20of\%20Performance.pdf 
Erdem, R., Pirinçci, E., Dikmetas s, E.,

2005 Üniversite ögrencilerinin zaman yönetimi davranıs, ları ve bu davranıs, ların akademik bas, arı ile ilis s, kisi (Relationship between time management behaviours and academic achievement of these behaviours of university students). Sosyal Bilimler Dergisi [Journal of Social Sciences] 14, 167e177.

Ferret, S. K.

2010 Peak Performance Success in College and Beyond. (7th Ed.). McGraw-Hill, New York.

Fredricks, J.A., Blumenfield, P.C. \& Paris, A. H.

2004 School Engagement: Potential of the concept, state of the evidence.

Review of Educational Research, 74(1), 59-109.

Kerby, M. B.

2007 Measuring student engagement activity levels and persistence: A study of a four-year comprehensive university. ProQuest Education Journals.

Kuh, G. D.

2003 What we're learning about student engagement from NSSE: Benchmarks for effective educational practices. Change, 35(2): 24-32.

Kyoshaba, M.

2009 Factors affecting academic performance of undergraduate students at Uganda Christian University. ProQuest Education Journals. Leone, M. \& Tian, R (2009). Push vs pull: Factors influence student retention. American Journal of Economics and Business Administration 1 (2): 122-132, 2009. ISSN 1945-5488

National Survey of Student Engagement (NSSE)

2005 Student Engagement: Exploring Different Dimensions of Student Engagement. Bloomington, IN: Indiana University Center for Postsecondary Research. Use Efficiency in Grade-Point-Average. Educational Research Quarterly, 27(4), 3-8. 
Nadinloyi, K. B., Hajloo, N., Garamaleki, N. S., \& Sadeghi, H.

2013 The study efficacy of time management training on increase academic time management of students. Procedia-Social and Behavioral Sciences, 84 , pp $134-138$.

Newmann, F.M.

1989 Student engagement and high school reform. Educational Leadership, 46 (5), pp 434-436.

Pehlivan, A.

2013 The effect of the time management skills of students taking a financial accounting course on their course grades and grade point averages. International Journal of Business and Social Science, vol. 4 (5).

Sansgiry, S., Bhosle, M., Sail, K.

2006 Factors that affect academic performance among pharmacy

students. American Journal of Pharmaceutical Education, 70 (5).

Tinto, V.

1975 Dropout from higher education: A theoretical synthesis of recent research. Review of Educational Research, 45, pp 89-125.

Tinto, V.

2006 Taking student retention seriously. Maricopa Community College. Retrieved from http://www.mcli.dist.maricopa.edu/fsd/c2006 /docs/takingretentionseriously.pdf 